\title{
ISSUE 10
}

10 EU-GRASP Policy Brief

March

2012

Changing Multilateralism: the EU as a Global-Regional Actor in Security and Peace, or EU-GRASP, is a European Union (EU) funded project under the 7th Framework Programme (FP7).

EU-GRASP aims to contribute to the articulation of the present and future role of the EU as a global and regional actor in security and peace.

Therefore, EU-GRASP is aimed at studying the processes, means and opportunities for the EU to achieve effective multilateralism despite myriad challenges.

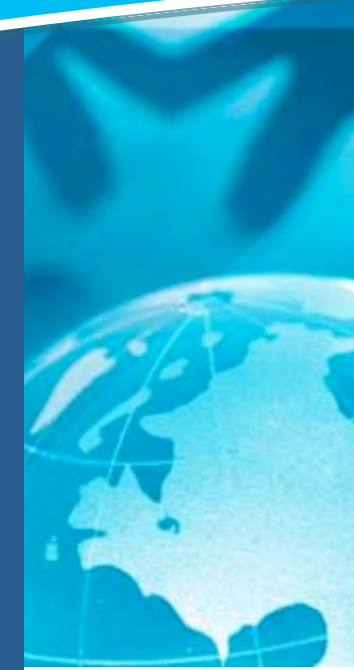

\section{Making the Transition: EU-China Cooperation on} Renewable Energy and Carbon Capture and Storage

By Sijbren de Jong*

(Katholieke Universiteit Leuven)

\section{Executive Summary}

Traditionally, Europe is considered to rank among the top performers in renewable energy. However, its lead in this area is increasingly challenged, notably by newcomer China. Keen to sustain its economic growth and ensure the availability of sufficient energy sources to that effect, China's progress in the field of renewable energy is as much about security of supply, as it is about counteracting the effects of environmental degradation and climate change. ${ }^{1}$

In its efforts to safeguard its economic growth, China is increasingly competing with the EU over scarce fossil fuel sources, such as natural gas from Central Asia. ${ }^{2}$ The focus of EU-China energy cooperation is therefore as much structured in terms of managing the latter's energy demand to limit its impact on climate change and the environment, as it is about relieving pressure on the Union's own security of supply.

Particularly since the second half of the 2000s, much has changed in China after the adoption of the Renewable Energy Law (REL or 'the Law') and the establishment of the EU-China Partnership on Climate Change at the 2005 EU-China summit. The Chinese renewable energy market has grown tremendously since and significant efforts have been put into cooperation on Carbon Capture and Storage (CCS) technologies. Despite of the renewable sector's growth, several obstacles remain in the way of its further development, including problems feeding renewable energy into the grid; restrictive regulations concerning foreign ownership; a lack of enforcement of regulations and follow-up on bilateral cooperation; and the absence of a regulatory system that favours carbon captured electricity.

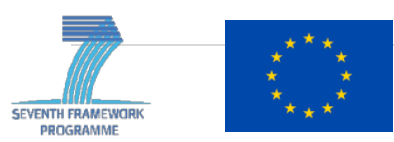




\section{The Chinese Renewable}

\section{Energy Market}

The REL established a number of important supporting regulations and guidelines. It set up guaranteed grid access which obliges power grid companies to acquire all electricity generated from renewable projects that are within the vicinity and coverage of their grids when sufficient power demand exists. $^{3}$ Moreover, as the costs of renewable energy are often higher than of conventional energy, the law stipulates this cost difference is ultimately levied on the end user. ${ }^{4}$ Next to grid access and cost sharing, the law provided for the establishment of a government sponsored special 'Renewable Energy Public Fund'. The fund was primarily set up in order to grant financial support to projects that stimulate renewable energy generation and development such as wind, solar and oceanic energy, rural clean energy projects and independent power systems construction in remote areas and outlying islands. ${ }^{5}$

Since the adoption of the REL and its associated measures, the Chinese renewable energy market has grown tremendously. Total renewable energy capacity in China reached 226 Gigawatt (GW) in 2009. ${ }^{6}$ China's $12^{\text {th }}$ Five-YearPlan sets a number of clear objectives to increase this number. Coal is to stay the dominant form of energy, whilst production of hydro-, wind-, biomass-, solar-, and nuclear power is to be enhanced. Hydropower is to be the 'backbone' of renewable energy with installed capacity forecasted to reach 280 Terawatt (TW) by 2015. Similarly, wind power capacity is set at 90 TW, biomass at 1.3 Megawatt (MW), nuclear at 30TW and solar at 5TW - all by 2015. In total, renewable energy will rise to a share of $11,4 \%$ of primary energy consumption. ${ }^{7}$ Ultimately, the plan is to direct China from a net importer of fossil fuels towards an exporter of renewable energy and energy efficiency technologies. The plan places emphasis on efficiency as a source for business, and aims to move towards smaller, distributed energy generation; away from large central hubs. The idea is to stimulate development of regional-scale energy enterprises across China. $^{8}$

Despite these impressive figures, the Chinese renewable energy market suffers from a number of problems. First, few technologies are fully commercialised and able to compete equally - both in terms of price and quality - with western technology; hydropower and biogas being the exception. ${ }^{9}$ Furthermore, according to some, the quality of Chinese renewable energy technology - photovoltaic in particular - is underpriced and does not correspond to EU standards. ${ }^{10}$ Greater financial contributions are necessary to improve this situation. However, the high cost of the most efficient technologies hinders their deployment. ${ }^{11}$ Moreover, often private companies are reluctant to invest during the earlier stages due to the low economic return, the risk of free-rider behaviour and intellectual property theft. ${ }^{12}$ Conversely, Chinese stakeholders frequently complain that companies in developed countries are able to monopolise access to clean technology and limit its transfer for private interests. ${ }^{13}$

Second, there is the difficulty to feed 
renewable energy - wind in particular into the Chinese grid as legally required by the REL. ${ }^{14}$ The main problem is reluctance on part of grid enterprises to build and expand grids to connect producers of wind energy. The reason is that many wind energy producers are in remote areas where generation circumstances are most optimal. However, grid operators feel that renewable energy's modest share of total electricity generation and its higher cost per KWh does not allow it to qualify for investing in innovation in this area. ${ }^{15}$ This issue is exacerbated by the fact that the Chinese market is dominated by a few large state owned companies who simultaneously own the energy infrastructure, making it harder for new players to enter the market. ${ }^{16} A$ further compounding factor is the Chinese renewable electricity sector's low operating efficiency, compared to other producers, such as the US. ${ }^{17}$

Third, given its modest share of total electricity generation it should be noted that, as renewable electricity will only make up around $20 \%$ of primary energy consumption by 2020 , there is a clear need for a strong strategy on non-electric renewable energy sources, such as biofuels, biogas, rural fuel wood and agricultural waste heating. ${ }^{18}$ However, the current scale of development and use is said to be still relatively small, causing China to have difficulties to reach its capacity target of $5000 \mathrm{MW}$ for 2010 and 30GW for 2020. Moreover, China restricted biofuel production from food feedstocks in $2007 .^{19}$ In a land that has scarce crops and arable land to sufficiently feed its population, Beijing views the biofuels debate as potentially treacherous.
Naturally, it would be interested in purchasing biofuels from elsewhere if doing so reduces its use of and dependence on fossil fuels. However, because of the aforementioned reason, it is wary to get actively and visibly involved in this debate, let alone support domestic production. $^{20}$

Fourth, investors and developers of wind power projects (those of more than $50 \mathrm{MW}$ in capacity) were selected through a concession bidding process whereby the winning bid is conditioned on the extent of 'local content' ${ }^{21}$ involved and the price offered per KWh. ${ }^{22}$ Recently, feed-in tariffs for wind energy were amended whereby the wind energy market was divided into four different geographical regions, each with its own tariff according to its ability to generate wind power energy; the best region get's the lowest tariff, the least well endowed regions the highest. ${ }^{23}$ The local content requirement was dropped. However, Prior experience has shown local content often mattered much less anyhow compared to price per $\mathrm{KWh}$ when it came to winning a bid. This results in a fierce price competition among bidders. What subsequently happens is that large (mostly state-owned) corporations, who possess profitable coal-fired, hydropoweror nuclear power stations, undercut competing bidders by setting their prices so low that the project could actually be considered economically undevelopable. ${ }^{24}$ The possibility for market entrants or smaller companies to make a successful bid however is thereby significantly reduced. Similarly, under such conditions the incentives for firms to invest in research and development which could improve the competitiveness of 
renewables are lower than they should be. ${ }^{25}$

A fifth and related issue has to do with the financial benefits for wind power projects to acquire Clean Development Mechanism (CDM) status. The costs of CDM wind power projects are lower compared to those without CDM backing, as the latter cannot benefit from Annex I Certified Emission Reductions (CER). ${ }^{26}$ However, in order to be eligible for CDM status a wind park must be for $51 \%$ owned by a Chinese company. Foreign investors argue that with such a restriction it is difficult for them to manage a company efficiently. The consequence is that given the nature of the bidding process - lowest price per KWh usually wins - it becomes impossible for foreign companies to factor in CDM income and hence get a decent chance at acquiring the concession. ${ }^{27}$

\section{EU-China Cooperation on}

\section{Carbon Capture and}

\section{Storage (CCS)}

According to the $12^{\text {th }}$ Five-Year-Plan energy consumption per unit of GDP is to decrease by $16 \%$ and $\mathrm{CO}^{2}$ emissions per unit of GDP is to be cut by $17 \%$. Emissions of Chemical Oxygen Demand (COD) and sulphur dioxide are to be reduced by $8 \%$, and ammonia nitrogen and nitrogen oxide by $10 \%$ - all by $2015 .^{28}$ Earlier, China had announced it would reduce the carbon intensity of its GDP by $40-45 \%$ by 2020 , relative to 2005 levels. ${ }^{29}$

Cooperation on CCS is a cornerstone of the EU-China Partnership on Climate Change. CCS is a promising technology, but at current development rates it is still far from commercialisation however. Partly this is due to the fact that the market in developing/emerging economies fails to reflect the real cost to society of the use of fossil fuels to generate electricity. ${ }^{30}$ In any event, $\mathrm{CO}^{2}$ capture and storage reduces overall process efficiency and increases the amount of fossil fuels used to achieve a given power generation output. ${ }^{31}$ Given the fact that more fuel is consumed, experts fear that the focus on $\mathrm{CO}^{2}$ capture technologies will lead attention away from much needed energy efficiency improvements and renewable energy development. Neglecting the importance of energy efficiency and renewables, they say can ultimately threaten energy security and the environment. ${ }^{32}$ Moreover, others assert that flue gas desulphurisation equipment - an often used technique ${ }^{33}$ causes a 4 to $8 \%$ reduction in production efficiency, thereby raising the final price. Consequently, even when Chinese operators possess the equipment, they often do not turn it on in order to save money. ${ }^{34}$ It should be noted here that this phenomenon is part of a broader lack of implementation and enforcement of regulations; a topic which cross-cuts every theme in EU-China cooperation and is not limited to environmental regulation alone. ${ }^{35}$

When compared to an Integrated Gasification Combined Cycle (IGCC) thermal power plant ${ }^{36}$ which is not equipped with CCS technology, the net Cost of Electricity (COE) produced by a CCS equipped IGCC plant is 44\% higher. ${ }^{37}$ In this case, the cost of capturing one ton of $\mathrm{CO}^{2}$ amounts to roughly $18 €$, and the cost of the $\mathrm{CO}^{2}$ avoided stands slightly higher at around $22,50 €$ per ton The costs of transporting the captured $\mathrm{CO}^{2}$ to a storage site were estimated at $€ 0,55$ 
per tonne per 100 miles. $^{38}$ Inevitably, such electricity is uncompetitive compared to the standard electricity sold on the Chinese market, unless an adequate regulatory framework is in place which favours types of electricity that emit less greenhouse gases. $^{39}$

The price differences set aside; there is much uncertainty over the possible capacity for $\mathrm{CO}^{2}$ storage in China. The study researched a number of oilfields, saline aquifers and unmineable coal beds in eastern China for their $\mathrm{CO}^{2}$ storage potential. The considered sites were the Dagang oilfield province in the Tianjin municipality, the Shengli oilfield province (Shandong), the Kailuan mining area (Hebei province), and the deep saline aquifers in the Jiyang Depression in Shandong province. ${ }^{40}$ Results show the Dagang oil province was estimated at 22 Megatonne (Mt) of $\mathrm{CO}^{2}$ storage capacity. Given this limited size it was deemed ineligible for large-scale storage. It does however exert potential for Enhanced Oil Recovery $(E O R)^{41}$ pilots. The Shengli field shows more potential in this respect with estimates ranging from $463 \mathrm{Mt}$ to $472 \mathrm{Mt}$. In the Kailuan mining area, geological barriers were found to inhibit large-scale storage as some of the coal is likely to be mined in the future and other formations have a too low degree of permeability. Finally, within the Jiyang Depression, the Huimin sub-basin's $\mathrm{CO}^{2}$ storage capacity was found to be enormous at an estimated 22 Gigatonnes (Gt). ${ }^{42}$ However, many uncertainties exist given the limited data availability due to a general lack of commercial interest in deep saline aquifers. $^{43}$ In addition, there are concerns that large-scale $\mathrm{CO}^{2}$ storage in deep saline aquifers results in acidity, which in turn can cause geological corrosion. ${ }^{44}$

A second study showed that in a carbon constrained scenario under the assumption of continued domination of coal; limited availability of renewable energy and no CCS; emission reductions would strongly depend on the instalment of nuclear capacity. If deeper emission cuts are needed, it would be necessary to create up to 1000 GigaWatt equivalent (GWe) of nuclear power. In addition, over $400 \mathrm{GWe}$ of coal-fired plants equipped with CCS technology would be required by 2050 as part of a portfolio of measures to achieve the greatest amount of $\mathrm{CO}^{2}$ emission cuts. ${ }^{45}$ Next to the obvious issues of public acceptance, site selection, safety and waste disposal, considerable other doubts exist with regard to such enormous nuclear expansion. Some experts view this as a negative factor for CCS deployment, given that large-scale growth in nuclear capacity could lead attention away from CCS technology and consequently slow the development of this important technology. ${ }^{46}$

A final issue relates to the fact that China's state-owned enterprises still dominate the transmission, distribution and sales of electricity. The current system's uneven distribution of profits makes it difficult to deploy CCS in China. Under current practice, the price on the grid is determined by competition and the final selling price by the grid companies. Should CCS technology be used therefore, this causes most profits to reside with the grid companies, whereas electricity companies are faced with rising 
costs of power generation without an equal adjustment in profits. ${ }^{47}$

\section{Recommendations}

One of the main obstacles is the monopolistic character of the Chinese energy market and the reluctance by state owned companies who simultaneously own the energy infrastructure to expand the grid to producers of 'competing energy'. Although, the $12^{\text {th }}$ Five Year Plan announced to allow private capital go get involved in these industries is hopeful, it could take a long time to increase competition, prevent companies from undercutting break-even prices on wind power concessions and invest more in R\&D. Therefore, in the short to medium term, the Chinese State could use money from the Renewable Energy Public Fund to extend favourable loans to renewable energy producers in remote regions to allow them to (partially) finance necessary grid expansions.

The current obligation for Chinese power companies to buy a given amount of renewable electricity relative to total electricity purchased proves a very useful feat in order to raise the competitiveness of renewables. However, in the long term it is preferred for China to introduce a kind of Renewable Portfolio Standard system, comparable to the one used in the US. However, given that by 2020 renewable electricity will only make up around $20 \%$ of primary energy consumption, it is recommended that such a system incorporates clear targets for nonelectric renewable energy sources, such as biofuels, biogas, rural fuel wood and agricultural waste heating. Should implementation of such a regulation prove too sensitive domestically, it is worth exploring possibilities for the larg(er) scale purchase of such fuels from abroad.

The minimum requirements placed on Chinese ownership of wind parks render it practically impossible for foreign companies to factor in Clean Development Mechanism income, and thus successfully bid for a concession. A recent study by the Oxford Institute for Energy Studies (OIES) however provides suggestions which could increase EU-China cooperation on wind park siting, development, and operations; grid development and extension; and the systems required to integrate and back up the generated power. ${ }^{48}$ The idea would be for China and the EU to engage in a Joint Commitment Framework Agreement (JCFA). Under, such a JCFA the EU would commit itself to financial, technical and policy support for wind park development in China, either through carbon offsets or Nationally Appropriate Mitigation Actions (NAMAs). The wind parks will reduce $\mathrm{CO}^{2}$ emissions coming from China; the 'amount' of which is subsequently purchased by the EU in the form of Certified Emission Reduction credits. In return, the Chinese commit themselves to adapt the $51 \%$ rule; ${ }^{49}$ thus improving foreign investors' abilities to manage the companies efficiently.

With respect to CCS and clean coal technology, one of the most pressing issues is the lack of a proper enforcement of regulations and followup on EU-China cooperation. ${ }^{50}$ The cause of the problems stems partly from the fact that both parties possess an intricate bureaucracy, causing multiple departments on both sides to work on a 
given issue, which can cause overlap, inefficiencies, or delays due to insufficient coordination. ${ }^{51}$ On the EU side, it was suggested to create a more efficient dialogue structure that incorporates future projects in one single operating framework; one which would allow the various projects to run on time and exert a higher level of discipline. It is important for such a framework to possess a disciplined reporting line which allows for a stronger form of accountability and for projects to stay on track. ${ }^{52}$

Furthermore, an effective regulatory framework concerning CCS and related technology is currently missing. CCS generated electricity requires more energy and is ultimately more expensive, thus there is a clear need for a regulatory system which 'rewards' electricity that exhaust less $\mathbf{C O}^{2}$. One way to achieve this is to introduce a 'Carbon tax' on electricity which exceeds a given amount of $\mathrm{CO}^{2}$ output during the generation process. ${ }^{53}$ Such a measure could benefit CCS generated power and allow it to compete more effectively with conventional and renewable electricity. Over time such taxes and subsidies can be phased out when CCS technology becomes more efficient and competitive. Furthermore, power generation should at the same time move away from treating $\mathrm{CO}^{2}$ as a 'waste product', towards viewing it as a useful by-product of electricity generation. The current industrial use of $\mathrm{CO}^{2}$ is very limited. The stimulation of industry to utilise $\mathrm{CO}^{2}$ for specific purposes, such as Enhanced Oil Recovery, could boost demand for CCS and help develop the value chain of CCS technology. ${ }^{54}$ 
${ }^{1}$ Ibid., Euractiv, 'Chinese giant strides into renewable technologies.

${ }^{2}$ In spite of the fact that the EU has been talking about acquiring Caspian gas for years, China has recently managed to open a direct pipeline to Turkmenistan. See BBC News, 'China president opens Turkmenistan gas pipeline', 14 December 2009. Available at: http://news.bbc.co.uk/2/hi/8411204.stm. Accessed on 30 May 2011.

F. Wang, H. Yin, and S. Li, (2009), 'China's renewable energy policy: Commitments and challenges', Energy Policy 38(4), p. 1873; J.H. Su, S.S. Hui, and H. Tsen, (2010), 'China Rationalizes Its Renewable Energy Policy', The Electricity Journal 23(3), p. 28; L. Mastny (ed.) (2010). Renewable Energy and Energy Efficiency in China: rent Status and Prospects for 2020. Worldwatch Institute. October 2010, p. 28; E. Martinot and L. Junfeng, (2010), 'Renewable Energy Policy Update For China', Renewableenergyworld.com, 21 July 2010, p. 3. Available at: http://www.renewableenergyworld.com/rea/news/article/2010/07/renewable-energypolicy-update-for-china. Accessed on 4 November 2010.

J.H. Su et al., (2010), supra note 4, p. 32.

${ }^{5}$ F. Wang et al., (2009), supra note 4, p. 1874; J.H. Su et al., (2010), supra note 4, p. 32.

${ }^{6}$ E. Martinot and L. Junfeng, (2010), supra note 4.

7 Delegation of the European Union in China, (2011), 'Full Translation 5yr Plan 20112015', pp. 3-4. Available at: http://cbi.typepad.com/china direct/2011/05/chinas-twelfthfive-new-plan-the-full-english-version.html Caijing, 'China Mapped out Energy Program During $12^{\text {th }} \quad$ Five-Year Plan', 22 October 2010. Available at: http://english.caijing.com.cn/2010-10-22/110549828.html. Both accessed on 17 May 2011.

${ }^{8}$ Global Fund Exchange Investing in the Future of Energy Blog, 'China's $12^{\text {th }}$ Five-Year Plan Emphasizes Clean Energy Exports', 10 January 2011. Available at: http://www.globalfundexchange.com/?p=3250\&option=com wordpress\&ltemid=267.

Accessed on 21 January 2011.

${ }^{9}$ X. Zhang, W. Ruoshui, H. Molin and E. Martinot, (2009), 'A study of the role played by renewable energies in China's sustainable energy supply', Energy 35(11), p. 4395; Z.Y. Zhao, J. Zuo, T. T. Feng, and G. Zillante, (2010), 'International cooperation on renewable energy development in China - A critical analysis', Renewable Energy 36(3), p. 1107.

10 Interviews with official from EU Member State Permanent Representations, 23 April and 20 May 2010.

${ }^{11}$ Q. Wang, (2009), 'Effective policies for renewable energy - the example of China's wind power - lessons for China's photovoltaic power', Renewable and Sustainable Energy Reviews 14(2), p.710; Z.Y. Zhao, et al., (2010), supra note 10, p. 1108.

${ }^{12}$ Various interviewees confirmed this view. Interview with research fellow of the Oxford Institute for Energy Studies in the margin of the EU-China Energy Conference, Shanghai, 9 July 2010; interview with officials from European Commission DG Research, 8 June 2010; interview with official from European Commission DG External Relations, 23 June 2010. See also X. Zhang et al., (2009), supra note 10, pp. 43974398; B. Buijs, (2009), China, Copenhagen and Beyond: The Global Necessity of a Sustainable Energy Future for China, (the Hague: Netherlands Institute of International Relations, Clingendael), p. 33; J. Holslag, (2010), 'China's Scepticism of Clean Energy Champion Europe', The International Spectator 45, p. 122. 
${ }^{13}$ EU-China CDM Facilitation Project. Key Findings and Recommendations, p. 4. Available at:

http://www.euchina-cdm.org/media/docs/EU-

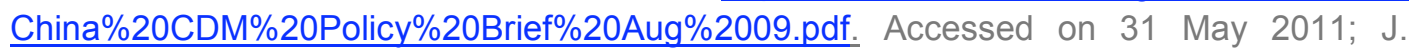
Holslag, (2010), supra note 13, p. 122.

${ }^{14}$ It is reported that up to one-third of wind energy generation capacity is not connected to the grid and thus remains idle. See S. Schuman, (2010), 'China Renews Its Commitment to Renewable Energy', National Resources Defense Council Staff Blog, 1 February 2010,

p. $1 . \quad$ Available at:

http://switchboard.nrdc.org/blogs/bfinamore/china renews its commitment to.html.

Accessed on 17 January 2011; and F. Wang et al., (2009), supra note 4, p. 1875.

15 REN21, (2009). Recommendations for Improving the Effectiveness of Renewable Energy Policies in China. October 2009, p. 26.

${ }^{16}$ X. Zhang et al., (2009), supra note 10, p. 4398.

17 According to Wang et al., in 2007 1MW of Chinese renewable electricity capacity generated 955MWh, compared to 1433 MWh in the US. See F. Wang et al., (2009), supra note 4, p. 1875.

${ }^{18}$ Interview with official from the Sino-Danish Renewable Energy Development Programme in the context of the July 2010 EU-China Energy Conference, Shanghai, 27 July 2010. See also U. Weber, (2010). 'Achieving China's Non-Fossil Fuel Target: Beyond the Electricity Sector'. Available at: http://dcbf.dk/Latest/From+DCBF/ca40/newsid/19804. Accessed on 20 January 2011.

${ }^{19}$ L. Mastny (ed.) (2010), supra note 4, p. 33.

${ }^{20}$ Interview with official of the European Commission DG Energy, 25 May 2010.

${ }^{21}$ Materials and components used which came from China.

${ }^{22}$ Q. Wang, (2009), supra note 12, pp. 705-706.

${ }^{23}$ E. Martinot and L. Junfeng, (2010), supra note 4., pp. 3-4; Renewable Energy Focus, 'China launches differentiated wind energy tariffs', 7 September 2009. Available at: http://www.renewableenergyfocus.com/view/3817/china-launches-differentiated-windenergy-tariffs/. Accessed on 20 January 2011

Q. Wang, (2009), supra note 12, pp. 706-707; B. Buijs, (2009), supra note 13, p. 37; Q. Wang and Y. Chen, (2010), 'Barriers and opportunities of using the clean development mechanism to advance renewable energy development in China', Renewable and Sustainable Energy Review 14(7), p. 1997.

${ }^{25}$ Interview with official from the Sino-Danish Renewable Energy Development Programme in the context of the July 2010 EU-China Energy Conference, Shanghai, 27 July 2010; F. Wang et al., (2009), supra note 4, p. 1876.

${ }^{26}$ Certified Emission Reductions (CER) are so-called 'Carbon Credits' which are issued by the Clean Development Mechanism Executive Board. CERs can be used by the Annex I parties - the industrialised countries - under the Kyoto Protocol in order to comply with their emission limitation targets.

${ }^{27}$ Interview with research fellow of the Oxford Institute for Energy Studies in the margin of the EU-China Energy Conference, Shanghai, 9 July 2010; B. Müller, D. Robinson, and Z. Xiliang (eds.), (2010). 'Addressing Large Developing Country Emissions'. Oxford, Oxford Institute for Energy Studies, pp. 27 and 46; EU-China CDM Facilitation Project. Key Findings and Recommendations, supra note 14, p. 5. 
${ }^{28}$ Delegation of the European Union in China, (2011), 'Full Translation 5yr Plan 20112015', pp. 3-4. Available at: http://cbi.typepad.com/china direct/2011/05/chinas-twelfthfive-new-plan-the-full-english-version.html: Caijing, 'China Mapped out Energy Program During $12^{\text {th }}$ Five-Year Plan', 22 October 2010. Available at: http://english.caijing.com.cn/2010-10-22/110549828.htm Both accessed on 17 May 2011.

E. Martinot and L. Junfeng, (2010), supra note 4.

${ }^{30} \operatorname{COM}(2009) 284$ final of 25 June 2009, p. 5.

${ }^{31}$ China-UK Near Zero Emissions Coal (NZEC) Initiative Summary Report, pp.8-9; L. Dapeng and W. Weiwei, (2009), 'Barriers and incentives of CCS deployment in China: Results from semi-structured interviews', Energy Policy 37(6), p. 2423; COM(2009) 284 final, supra note 31 , p. 5.

${ }^{32}$ L. Dapeng and W. Weiwei, (2009), supra note 32, p. 2424

${ }^{33} \mathrm{~A}$ technology used to remove sulphur dioxide from the exhaust flue gases of fossil fuel power plants through the use of a chemical solvent which scrubs off the flue gas stream.

${ }^{34}$ B. Buijs, (2009), supra note 13, pp. 71-72.

${ }^{35}$ Interview with official from European Commission DG Energy, 9 November 2010; interview with officials from European Commission DG Research, 8 June 2010; interview with official from European Commission DG External Relations, 23 June 2010; B. Buijs, (2009), supra note 13, p. 33. See also European Commission, 'China Strategy Paper 2007-2013', pp. 25-26.

${ }^{36}$ An IGCC thermal power plant turns coal into gas. The plant removes impurities from the coal before it combusts in an attempt to turn any pollutants into usable by-products Sulphur dioxide, particulates and mercury emissions of such a plant are lower compared to traditional coal-fired power plants. The excess heat from the primary combustion and generation process is also used to power a steam cycle which results in improved efficiency in comparison with conventional pulverised coal plants.

${ }^{37}$ The analysis is based on the assumption that both type of plants run 7000 operating hours per year. See $\mathrm{COACH}$ Cooperation Action within CCS China-EU Executive Report, p. 30.

${ }^{38}$ The transportation costs were calculated based on the following assumptions. The $\mathrm{CO}^{2}$ flowrate was estimated at 3 million tonnes per year with a pipeline diameter of $300 \mathrm{~mm}$. The facility's lifetime was set at 20 years, with the pipeline's capital expenditure estimated at $€$ 21,500 per mile and its operational expenditures at $€ 3450$ per mile per year. See $\mathrm{COACH}$ Report, supra note 38, pp. 30-31.

${ }^{39}$ COACH Report, supra note 38, pp. 11, 13-14 and 30; L. Dapeng and W. Weiwei, (2009), supra note 32, p. 2425; H. Duan, (2010), 'The public perspective of carbon capture and storage for $\mathrm{CO}^{2}$ emission reductions in China', Energy Policy 38(9), pp. 5821-5822; $\operatorname{COM}(2009) 284$ final, supra note 31 , p. 5.

${ }^{40} \mathrm{COACH}$ Report, supra note 38, p. 17.

${ }^{41}$ Enhanced Oil Recovery is the process of injecting $\mathrm{CO}^{2}$ into mature oil fields to improve the recovery of oil.

${ }^{42} \mathrm{COACH}$ Report, supra note 38, pp. 17-19; and 28-30.

${ }^{43}$ China-UK Near Zero Emissions Coal , supra note 32, pp.7-8 and 21. 
${ }^{44}$ L. Dapeng and W. Weiwei, (2009), supra note 32, p. 2424.

${ }^{45}$ China-UK Near Zero Emissions Coal, supra note 32, pp. 12-13.

${ }^{46}$ L. Dapeng and W. Weiwei, (2009), supra note 32, p. 2425.

${ }^{47}$ Ibid., pp. 2429-2430.

${ }^{48}$ B. Müller, D. Robinson, and Z. Xiliang (eds.), (2010), supra note 28, p. ii; interview with research fellow of the Oxford Institute for Energy Studies in the margin of the EU-China Energy Conference, Shanghai, 9 July 2010.

${ }^{49}$ Ibid.

${ }^{50}$ Interview with officials from European Commission DG Research, 8 June 2010; interview with official from European Commission DG Energy, 9 November 2010.

${ }^{51}$ Interview with official of the European Commission DG External Relations, 23 June 2010.

52 Ibid.

${ }^{53}$ L. Dapeng and W. Weiwei, (2009), supra note 32, pp. 2426-2427.

${ }^{54}$ Ibid., pp. 2429 and 2431. 